\title{
Power Crisis and Solution in Bangladesh
}

\author{
Mohammad Asadul Haque ${ }^{\mathrm{a}}$ and Jalalur Rahman ${ }^{\mathrm{a} *}$ \\ ${ }^{a}$ Department of Physics, University of Chittagong, Chittagong, Bangladesh and \\ ${ }^{b}$ Department of Applied Physics, Electronics and Communication Engineering, University of Dhaka, Bangladesh
}

\begin{abstract}
Crisis of power is one of the major problems in Bangladesh. Day by day the gap between demand and production is increasing. Moreover, most of the power plants are gas based which will be phased out in future. Misuse, system loss and corruption in power sector are the main issue regarding this crisis. It is possible to control load demand by using compact fluorescent lamp (CFL), transformation of holiday, proper load management, encouraging Independent Power Producers (IPP) and reducing transmission loss. Priority should be given to control misuse and corruption in power sector than generation of power. Proper utilization of renewable energy is the up most choice for solving the power crisis in Bangladesh because it requires low cost and less risk. Initiative should be taken to develop skilled manpower required for the power sector considering renewable energy sources. By incorporating IPP and local Government (GOV), central GOV may take the responsibility to increase the power generation and ensure its proper use in Bangladesh.
\end{abstract}

Key words: Power crisis, Compact fluorescent lamp, Load management, Renewable energy.

\section{Introduction}

Power plays a great role wherever people lives and works in industry, agriculture, and transportation etc. The living standard and prosperity of a nation vary directly with increase in use of power. As technology is advancing the consumption of power is steadily rising. Sufficient and reliable source of electricity is a major prerequisite for a sustained and successful economic development effort and poverty reduction. In Bangladesh, 90 million of the populations out of 140 million do not have direct access to electricity and remaining 50 million people have access but reliable and quality power is still beyond their reach (BPDB, 2007). In order to achieve the growth rate, availability of a reasonably priced and reliable source of electricity is a prerequisite. Present generation of electric power in Bangladesh is not sufficient to meet the consumers growing demand. So it is not possible to ensure a constant supply of electric power to all consumers throughout the country. Moreover the demand is increasing day by day. So it is essential to set up more generating station for over demanding load.

On the other hand, the existing power stations have lost their lifetime; they are not reliable for steady generation. So it has to be replaced old generating units in various power stations. Shortage of power is serious problem and strong barrier for

\footnotetext{
* Corresponding author: asad2310@gmail.com
}

the development of our country. GOV of Bangladesh has so many limitations to set up sufficient power station. The GOV has given top priority to development of the sector considering its importance in overall development of the country. The GOV has set the goal of providing electricity to all citizens by 2020 .

\section{Present status of power sector in Bangladesh \\ Present structure of power sector:}

Different utilities are working under the guidance of Power Division, Ministry of Power, Energy \& Mineral Resources (MPEMR):

\section{Generation}

Bangladesh Power Development Board (BPDB), Independent Power Producers (IPPs), Electric Generation Company of Bangladesh Ltd. (EGCB)

Transmission

Power Grid Company of Bangladesh Ltd. (PGCB)

Distribution

Bangladesh Power Development Board (BPDB), Dhaka Electric Supply Company Ltd. (DESCO), 
Dhaka Power Division Company Ltd. (DPDC),

Rural Electrification Board (REB) through Rural electric Co-operatives called Palli Bidyut Samati (PBSs), West Zone Power Distribution Company Ltd. (WZPDC)

Formation stage

North Zone Power Distribution Company Ltd. (NZPDC),
South Zone Power Distribution Company Ltd. (SZPDC), Central Zone Power Distribution Company Ltd. (CZPDC)

\section{Overview of power stations in Bangladesh}

At present, BPDB operates 30 power stations (Including IPP) with a total installed capacity of 5466 MW. The information about power stations are shown in Table I: (MPEMR, 2008)

Table I. Information about power stations in Bangladesh

Public Sector

\begin{tabular}{|c|c|c|c|c|c|c|}
\hline $\begin{array}{l}\text { S. } \\
\text { No }\end{array}$ & Power Station & $\begin{array}{c}\text { No } \\
\text { of units }\end{array}$ & Types of units & Type of fuel & $\begin{array}{c}\text { Installed } \\
\text { Capacity MW }\end{array}$ & $\begin{array}{c}\text { Generation } \\
\text { capacity MW }\end{array}$ \\
\hline 1 & Karnafuli & 5 & Hydro & Hydro & 230 & 230 \\
\hline 2 & Ashuganj & 8 & $\begin{array}{l}\text { Steam Turbine } 5 \\
\text { Combined Cycle } 3\end{array}$ & Gas & 744 & 610 \\
\hline 3 & Siddhirganj & 2 & Steam Turbine & Gas & 260 & 245 \\
\hline 4 & Haripur & 3 & Combustion Turbine & Gas & 99 & 90 \\
\hline 5 & Tongi & 1 & Combustion Turbine & Gas & 105 & 105 \\
\hline 6 & Ghorasal & 6 & Steam Turbine & Gas & 950 & 820 \\
\hline 7 & Shahjibazar & 6 & Combustion Turbine & Gas & 166 & 80 \\
\hline 8 & Fenchuganj & 3 & Combined Cycle & Gas & 90 & 90 \\
\hline 9 & Sylhet & 1 & Combustion Turbine & Gas & 20 & 20 \\
\hline 10 & Raozan & 2 & Steam Turbine & Gas & 420 & 360 \\
\hline 11 & Sikalbaha & 2 & $\begin{array}{l}\text { Steam Turbine } 1 \\
\text { Combustion Turbine } 1\end{array}$ & Gas & 116 & 62 \\
\hline 12 & Khulna & 4 & $\begin{array}{l}\text { Steam Turbine } 2 \\
\text { Combustion Turbine } 2\end{array}$ & F. Oil & 226 & 168 \\
\hline 13 & Bheramara & 3 & Combustion Turbine & High speed Diesel & 60 & 56 \\
\hline 14 & Saidpur & 1 & Combustion Turbine & High speed Diesel & 20 & 20 \\
\hline 15 & Thakurgaon & 3 & Diesel & Light diesel oil & 4.5 & 2 \\
\hline 16 & Barishal & 5 & $\begin{array}{l}\text { Diesel } 3 \\
\text { Combustion Turbine } 2\end{array}$ & High speed Diesel & 47.14 & 37 \\
\hline 17 & Rangpur & 1 & Combustion Turbine & High speed Diesel & 20 & 19 \\
\hline 18 & Bhola & 6 & $\begin{array}{l}\text { Diesel } \\
\text { High speed Diesel } 2\end{array}$ & F. Oil 1 & 6.76 & 4.6 \\
\hline 19 & Baghabari & 2 & Combustion Turbine & Gas & 171 & 171 \\
\hline 20 & Barapukuria & 2 & Steam Turbine & Coal & 250 & 205 \\
\hline 21 & Rooppur & 15 & Nuclear & Nuclear fuel & 600 & Proposed \\
\hline \multicolumn{7}{|c|}{ Private Sector } \\
\hline 1 & NEPC Haripur (BMPP) & 8 & Diesel & Gas & 110 & 110 \\
\hline 2 & RPC (Mymenshingha) & 4 & Combustion Turbine & Gas & 140 & 140 \\
\hline 3 & CDC Haripur & 1 & Combustion Turbine & Gas & 360 & 360 \\
\hline 4 & CDC Meghnaghat & 3 & Combustion Turbine & Gas & 450 & 450 \\
\hline 5 & KPCL (BMPP) & 18 & Diesel & F. Oil & 110 & 110 \\
\hline \multirow[t]{2}{*}{6} & Baghabari BMPP & & & & & \\
\hline & West Mont (WPL) & 2 & Combustion Turbine & Gas & 90 & 88 \\
\hline 7 & Khulna Barge-mounted & 2 & Combustion Turbine & oil & 56 & 40 \\
\hline 8 & Sikhalbaha Barge-mounted & 2 & Combustion Turbine & oil & 56 & 40 \\
\hline
\end{tabular}


From the above chart it is clear that most of power plants in Bangladesh are using natural gas as fuel about $81.43 \%$ of the total capacity. Other power stations are based on 5.34\% furnace oil, $4.08 \%$ diesel, $4.39 \%$ hydro and $4.77 \%$ coal (Pub. Of spilling energy, 2008).

The installed capacity of power station including IPP is shown in Table II: (www.bpdb.gov.bd and Mansoor S.A. et. al. 2004)

\section{Crisis of Power in Bangladesh}

Electricity has given modern and sophisticated life in the world. It is impossible to imagine the civilized world without electricity. In Bangladesh the crisis of power is the common phenomena. Now a day it has become the serious problem. The reasons for lower availability are (1) some plants are out of operation for maintenance, rehabilitation \& overhaul, (2) capacity of some plants are derated due to aging and (3) gas shortage.

\section{Table II. Installed Capacity}

\begin{tabular}{|c|c|c|c|}
\hline \multicolumn{2}{|c|}{ By type of plant } & \multicolumn{2}{|c|}{ By type of fuel } \\
\hline Hydro & $230 \mathrm{MW}(4.60 \%)$ & Gas & 4,216.00 MW (85.51\%) \\
\hline Steam Turbine & 2,435 MW (48.81\%) & Furnace oil & 249.75 MW (5.80\%) \\
\hline Gas Turbine & 1009 MW (22.00\%) & Diesel & $204.60 \mathrm{MW}(4.09 \%)$ \\
\hline Combined Cycle & 990 MW (19.82\%) & Hydro & 230.00MW (4.60\%) \\
\hline Diesel & $238 \mathrm{MW}(4.76 \%)$ & & \\
\hline Total: & $4800 \mathrm{MW}(100 \%)$ & Total: & $4800 \mathrm{MW}(100 \%)$ \\
\hline
\end{tabular}

Power crisis is the result of transmission loss (technical loss and non technical loss), machinery loss, distribution loss and corrupt management. Non-technical losses are Consumption loss, billing loss and collections loss. As the demand of electricity is increasing so it is essential to set up new power stations to overcome the excess demand. But in our country being short of huge fund it could not be possible to build up new power stations. On the other hand the life time of the old power stations is over. In that case some times some of the units or whole station collapsed. For that reason the national grid break down and whole nation goes to dark.

\section{Present Generation and Demand (December, 2008)}

Installed Capacity: 5466 MW [Including IPP] Available Generation: 4415 MW [Including IPP]

Maximum Demand: $4800 \mathrm{MW}$

Shortage: Average $385 \mathrm{MW}$

\begin{tabular}{|l|l|}
\begin{tabular}{|l|l|} 
Dhaka Zone \\
Capacity: 3063 MW \\
Generation: 2455 MW \\
Demand: 1819 MW \\
Balance: + 636 MW
\end{tabular} & $\begin{array}{l}\text { West Zone } \\
\text { Capacity: 476 MW } \\
\text { Generation: 389 MW } \\
\text { Demand: 698 MW } \\
\text { Balance: -309 MW }\end{array}$ \\
\hline \begin{tabular}{l|} 
Central Zone \\
Capacity: 567 MW \\
Generation: 480 MW \\
Demand: 485 MW \\
Balance: -5 MW
\end{tabular} & $\begin{array}{l}\text { South Zone } \\
\text { Capacity: 773 MW } \\
\text { Generation: 618 MW } \\
\text { Demand: 1047 MW } \\
\text { Balance: -429 MW }\end{array}$ \\
\hline $\begin{array}{l}\text { North Zone } \\
\text { Capacity: 593 MW } \\
\text { Generation: 479 MW } \\
\text { Demand: 751 MW } \\
\text { Balance: -272 MW }\end{array}$ \\
\hline
\end{tabular}

Information on power crisis in Bangladesh is shown in Table III: (Pub. Of spilling energy, 2008)
Table III. Data on power crisis in Bangladesh

\begin{tabular}{l|c|c|c|c}
\hline Year & $\begin{array}{c}\text { Installed } \\
\text { capacity } \\
\text { (MW) }\end{array}$ & $\begin{array}{c}\text { Generation } \\
\text { capability } \\
\text { (MW) }\end{array}$ & $\begin{array}{c}\text { Demand } \\
\text { forecast } \\
\text { (MW) }\end{array}$ & $\begin{array}{c}\text { Load } \\
\text { shedding } \\
\text { (MW) }\end{array}$ \\
\hline 2003-04 & 4680 & 3592 & 4259 & 694 \\
$2004-05$ & 4685 & 3782 & 4375 & 800 \\
$2005-06$ & 4690 & 3810 & 4490 & 1312 \\
$2006-07$ & 4693 & 3849 & 4550 & 1212 \\
$2007-08$ & 5466 & 4415 & 4800 & 385 \\
\hline
\end{tabular}

Steps taken for enhancing power sector in Bangladesh

GOV of Bangladesh has made vision and policy statement regarding power sector improvement. It is GOV's constitutional responsibility to provide electricity to the people. In the vision statement it is mentioned that providing access to affordable and reliable electricity to the majority of the peo- 
ple of Bangladesh by 2020 is a national goal of the next millennium. For that purpose GOV issued its vision and policy statement on power sector reforms with the following objectives:

1. Bringing the entire country under electricity service by the year 2020 in phases.

2. Making the power sector financially viable and able to facilitate economic growth.

3. Introducing new corporate culture in the power sector entities and increasing the sector's efficiency.

5. Improving the reliability and quality of electricity supply.

6. Ensuring reasonable and affordable price for electricity by pursuing least cost options.

GOV is currently working with an interim target of providing electricity to $60 \%$ of the population by 2010 . At present electricity coverage in Bangladesh is only $43 \%$ and per capita electricity consumption is about $140 \mathrm{kWh}$ which is one of the lowest in the world (BPDB, 2007).

For solving the power crisis Government has taken the following steps:

\section{Renewable Energy Program}

\section{a) Solar Energy Project}

Infrastructure Development Company Ltd. (IDCOL) promotes Solar Home Systems (SHSs) under the Rural Electrification and Renewable Energy Development Project (REREDP). GOV has taken a solar energy development programme in the Chittagong hill tracts area.

Out of two projects one has successfully completed in Juraichhri area of Rangamati. Under that scheme about 600 homes have been electrified. 2nd phase has been taken up in Thanchi Upozila of Rangamati district. This project includes, 600 SHSs of 120 WP each, 20 sets Solar Photovoltaic (PV) street light systems of 75 WP each, 2 set Solar PV submersible water pumps of 50,000 liters per day lifting capacity of each pump of 1800 WP each, 6 Sets of Solar PV Vaccine Refrigerators for the Health Care Centers of $360 \mathrm{WP}$ each .1 Sets of $10 \mathrm{KW}$ Centralized AC market electrification systems for the electrification (EEE, IUT, 2008). Rural Electrification Board (REB) has taken three solar PV projects in different areas of Bangladesh which are as follows:

Project one has been started in 1994 and completed 1998 in the two unions of Narshingdi Sadar Thana (Karimpur \& Nazarpur) by the river Meghna. Under that programme, about 1000 numbers of various categories were benefited.

Project two targeted mainly Austragram (Kishoreganj), Shingra (Natore), Kotalipara (Gopalganj), Moheskhali, Kutubdia and St. Martine islands of the Bay of Bangal (Cox's Bazar). Main objective of the project is to provide 6000 nos. PV Solar Home System to the remote and isolated rural areas.

Project three targets are Sirajganj, Natore, Pabna, Barisal,Cox's bazar and Sunamganj. The main objective of the Project is to provide 16000 SHSs in Rural areas and about 80,000 people will be benefited.

On the other hand in case of solar energy program IPP and some private organization such as Brac Bangladesh, Summit Power, Grameen Shakti, Rahim Afroaz and ENERGYPAC are playing significant role.

\section{b) Biomass Based Power Plant Project}

IDCOL financed a $250 \mathrm{~kW}$ biomass based power plant at Kapasia, Gazipur. The plant uses locally available agricultural residues i.e. rice husk as fuel for power generation. Being an un electrified area, the plant is expected to supply environment friendly grid quality power to 300 households and commercial entities of that area. IDCOL is implementing National Domestic Biogas and Manure

Programme (NDBMP) with the support from GOV and Netherlands. The overall objective of the NDBMP is to develop and disseminate domestic biogas plants in rural areas with the ultimate goal to establish a sustainable and commercial biogas sector in Bangladesh.

\section{c) Wind Energy Project}

BPDB has taken a pilot project for installation of $500 \mathrm{KW}$ wind energy power station at Muhuri Dam area of Feni which gives the satisfactory performance of the mills. A comparative and comprehensive study shows that there exists a satisfactory potential for installation of wind mills in Bangladesh. Bangladesh GOV has taken a project for installation of $2000 \mathrm{KW}$ wind mills in different places of coastal area. Another projects have been taken from BPDB own 
fund at Kutubdia island named "1000 KW Wind-Battery Hybrid Power Plant Project" in Cox,s Bazar. (Compre. Report on wind, 2007 and www.reein.org/wind)

\section{Nuclear Power Plant}

The International Atomic Energy Agency (IAEA) recommended that Bangladesh may use nuclear power for electricity generation from $125 \mathrm{MW}$ to $600 \mathrm{MW}$. The government proposed a project Rooppur Nuclear Power Plant (RNPP) of installed capacity $600 \mathrm{MW}$ in 1961. Bangladesh Atomic Energy Commission (BAEC) has been set up Atomic Energy Research Establishment (AERE) at Savar in 1986 of installed capacity $20 \mathrm{MW}$ that is used only research purpose. BAEC has trained up a good number of professionals in various branches of nuclear technology to be involved in different implementation of phases of RNPP. For the development of nuclear sector BAEC created Nuclear safety \& Radiation Control Division (NSRCD) and Division of Nuclear Safeguards (DNS) to conducts the following activities:

1. Obligations under nuclear power plant and non proliferation including establishment of state system of accounting and control.

2. Implementation and enforcement of safeguards legislations and relevant safeguards procedures.

3. Physical security of nuclear materials and performing all regulatory activities under rules 1997.

Though many issues relating to cost, financing and safety are yet to be resolved but GOV is trying to solve all obligations regarding nuclear power.
Besides that BPDB has completed a pilot project for installing $50 \mathrm{KW}$ mini hydro plant at Borcol from its own revenue fund. GOV encourages industries to install their own small electricity generating plants so that they can continue uninterrupted production during the load shedding. Private power companies are also allowed to produce and supply power to the national grid under agreed terms. Bargemounted plants are the result of first such initiatives by the private sector. The private sector power plants that have recently started production include those at Baghabari (110 MW), Haripur (110 MW and 360 MW), Khulna (110 MW), Mymensingh (60 MW) and Meghnaghat (450 MW) all under the IPP (EEE, IUT, 2008).

\section{Future Development Plan}

BPDB's vision is to provide quality and reliable electricity to the people of Bangladesh for desired economic, social and human development of the country undertaking institutional and structural reforms leading to the creation of a holding company. Government has developed short-term (up to 2007), medium-term (up to 2012) and long-term (up to 2020) development plans. For that vision Governments missions are:

* To deliver quality electricity at reasonable and affordable prices with professional service excellence.

* To make electricity available to all citizens on demand by the year 2020 .

* To provide specialized skilled services in Operation and Maintenance with outstanding performance in genera

Table IV. A summary of the power development plan up to 2020

\begin{tabular}{l|c|c|c|c}
\hline Item & \multicolumn{2}{|c}{ Year } & \\
\hline & $2004-2005$ & $2005-2007$ & $2008-2012$ & $2013-2020$ \\
\hline Installed Capacity, MW & 5,025 & 6.441 & 9,666 & 17,765 \\
Peak Demand, MW & 3,743 & 5,368 & 7,887 & 14,600 \\
Net Generation, MKWh & 20,932 & 26,651 & 39,157 & 76,545 \\
Transmission Line, Km & 4,038 & 4,898 & 7,180 & 8,396 \\
Capacity of Grid S/S, MVA & & & & 19,075 \\
(a) 230/132 KV & 4,150 & 5,950 & 11,575 & 27,367 \\
(b) 132/33 KV & 7,644 & 9,642 & 17,920 & $4,77,558$ \\
Distribution Line, Km & $2,42,832$ & $2,66,375$ & $3,45,530$ & 20.76 \\
No. of Consumers, million & 8.84 & 9.03 & 12.75 & 84,000 \\
No. of Village Electrified & 47,848 & 52,071 & 69,571 & 450 \\
Per Capita Generation, KWh & 158 & 190 & 260 & $100 \%$ \\
Access to Electricity & $38 \%$ & $47 \%$ & $65 \%$ & 575 \\
Investment Requirement, (billion Tk) & 0 & 115 & 307 & \\
\hline
\end{tabular}


tion, transmission and distribution for promoting competition among various power sector entities.

* To follow international standard and adopt modem technology and practices in power generation activities.

* To ensure improved and satisfactory services to the consumers.

Under that mission last caretaker government planned for adding $1100 \mathrm{MW}$ but by December they have successfully added only $322 \mathrm{MW}$ in national grid. New government planned to add another $731 \mathrm{MW}$ electric power in national grid by June 2009. They stated that in January 157.5 MW, February 131 MW, March 287.5 MW, May 105 MW, June $50 \mathrm{MW}$ will be added in national grid (www bpdp. gov.bd).

A summary of the power development plan up to 2020 is shown in Table IV :( www.bpdb.gov.bd):

\section{Proposal for overcoming power crises in Bangladesh}

\section{Reducing system losses}

System losses play the major role in case of power crisis in Bangladesh. At least 25\% of total demand could be fullfilled by reducing system loss. Technical and non-technical system loss could be removed by taking the following steps:

\section{a For reducing technical system loss}

1. Disconnect the illegal connection of electricity. In that case law enforcing agencies take the initiative. There should be punishment to the charged people.

2. Connect the modern error free meter and implement the meter sealing system.

3. Whole billing system should be under computer network and dues should be collected properly.

\section{b For reducing technical system loss}

1. Latest technology should be implemented for the distribution of electricity. Insulated cable may used in the overhead transmission line. It is essential to modernize the distribution line, replace the old set up of the transformers, switch gear as early as possible. Lifetime and maintenance of all technical equipments should be ensured properly.

2. Employees of all levels must be responsible for their respective duties. As it is a technical work all employees should have the vast idea in this field. Administration should be ensued severe punishment for the dishonest employees and power station should be close to the load center.

\section{Utilization of energy saving lamp}

CFL or energy saving lamp can play a vital role to reduce the power crisis. CFL is a glorious energy saving lamp. Average ordinary lamp energy consumes 60 to $100 \mathrm{~W}$ and tube light 40W. But CFL energy consumes only 9W and its intensity of lumen is higher than ordinary lamp. At present only for lighting load electricity is required more than 600MW. If $80 \%$ of the huge demand is brought into under use of CFL, then at least 300MW will be saved this is completely equivalent of set up a generating station of 300MW. To provide CFL at cheapest rate GOV should provide tax free import of CFL then customer can get easily and subsidies should be given to encourage local manufacturers of CFL.

\section{Proper load management}

Load management means proper distribution and use of electricity. It could be suggested that for keeping load shedding at a minimum level GOV should take the following initiatives:

1. Government should take motivational programs to enhance awareness of the consumers during peak hours. Campaign should be essential to request the consumers through electronic and print media to be rational and economical in electricity use during peak hour by switching off, unnecessary loads like extra lighting, ironing, pumps, air conditioners and welding machines etc.

2. Industries and large commercial customers like shopping malls should use their own captive generation and GOV could transfer holiday in the markets and industrial belts.

3. Implementation of pre-paid metering system will give additional facility.

\section{Encourage Independent Power Producers (IPP)}

The GOV should encourage owner of industry or factory to install their own small electricity generating plants to continue uninterrupted production during the load shedding. For this, GOV should help them to supply adequate gas as a subsidized rate and ensure tax-free imports spare parts of gas generator. GOV should involved more power producer like Summit power in IPP.

\section{Expansion of renewable energy program}

\section{a) Development in solar energy program}

There are few renewable energy centre and these are not well established compared with other countries. So experts are 
not being coming out from there. Due to the crisis of huge fund and experienced manpower Bangladesh imports solar cell from abroad and only making panel is available here. For that reason it is costly and difficult to use, so customers are not interested to use solar panel. But solar energy program has glorious opportunity in Bangladesh. GOV has already been taken a solar energy development program in the Chittagong hill tracts area. This program should expand in the rural areas of the whole country. For enhancing solar energy program it is required to established at least 10 modern renewable energy research centre from where professional experts will come who can train others. For huge fund there public-private partnership program may be built up. Encourage IPP to expand their program. Champaign should be essential to aware the people to use solar panel and GOV should give subsidizes to import solar cell.

\section{b) Expansion of wind energy program}

For power generation the average wind speed is $5 \mathrm{~m} / \mathrm{sec}$ at a height 20-30 m. The average wind speed of some costal area at a height $25 \mathrm{~m}$ in Bangladesh is shown in table 5 (Compre. Report on wind, 2007 and www.reein.org/wind):

Table V. Wind speed of different places in Bangladesh

\begin{tabular}{l|c|c}
\hline Area & $\begin{array}{c}\text { Max. Speed for some } \\
\text { time m/sec }\end{array}$ & $\begin{array}{c}\text { Ave. yearly } \\
\text { Speed m/sec }\end{array}$ \\
\hline Potenga & 15 (8 months) & 4.2 \\
Anwara & 14 (6 months) & 4.1 \\
Teknaf & 16 (7 months) & 4.6 \\
Feni (Muhuri) & 15 (5 months) & 4.0 \\
Kutubdia & 16 (9 months) & 5 \\
Kuakata & 16 (9 months) & 5 \\
Char Fassion & 16 (6 months) & 3.8 \\
St. Martins & 20 (9 months) & 5.5 \\
\hline
\end{tabular}

From the above chart it is clear that there is a prospect of wind Energy Program in Bangladesh. As pilot project has successfully been completed and many local \& international organizations such as Bangladesh University of Engineering and Technology (BUET), Solar and Wind Resource Assessment (SWERA), Wind Energy Study (WES), BAEC reports that there is a scope for wind power energy in Bangladesh, so GOV should take initiative to produce electricity from wind power commercially. Private organizations like Grameen shakti can participate to enhance the sector. On the basis of research organizations report and collaborating with IPP and local government, central government should take the necessary steps for enhancing this sector.

\section{c) Enhance biogas plant for power generation}

Biogas is produced by the decomposition of animal, plant and human wastage. Biogas plant could be established in the remote area where there is availability of those wastage. For implementing this, GOV should encourage IPP to set up biogas plant like Gazipur by giving technical and financial support. In that case if the wastage of dairy can be used as rawmaterials then there is a good prospect of biogas power plant in dairy rich area like Gazipur, Norshingdi, Narayonganj, Savar and manikganj.

It should strongly be recommended that there is a bright future for biogas plant in the city corporation area like Dhaka, Chittagong, Khulna, Rajshahi, Sylhet and Borishal where thousand ton of wastage are wasting everyday which is polluting our environment. If those wastage can utilize properly then we can get power as well as we can save our environment from pollution.

\section{Sugar Co-generation project}

Prospects of sugar Co-generation power plant there after installation of as many as 10-15 nos. of generator having 1015 MW capacity each in the northern zone of Bangladesh where bagasse are available from the sugar mills. Cost will also be economical compared to the cost of generation of electricity by using fuel oil.

\section{Implementation of Nuclear Power Plant}

There is a huge gap between supply and demand which is increasing day by day. Since maximum power plants are gas based and proven gas reserve is reducing and no new gas reserve has been discovered yet. This huge gap cannot be met by renewable energy. In that case nuclear power may be the alternative option for generating electricity. Nuclear power could be a reality to bridge between the huge gaps between supply and demand. In the modern world, nuclear power has already been proved as cheap, reliable and safe. Now-a-days, the proven power rector design has achieved significant success in the forms of safety. Nuclear power station could be implemented in the western zone of the country and hilly region where there is scarcity of electricity. In fact, this issue was considered in the early 1960 and Rooppur Nuclear power station project was proposed 1961which could not be implemented mainly due to financial constraint. 
As per recommendation of IAEA it could be set up three nuclear power plants of installed capacity $600 \mathrm{MW}$ in different places of the country such as Rooppur (Ishordi) already proposed, Hill tracks Chittagong and Sylhet that may cover $40 \%$ of the total demand. Milestones in the development of a national infrastructure for nuclear power:

Human resources development, stakeholder involvement, national position, nuclear safety, management, funding and financing, legislative framework, safeguards, regulatory framework, radiation protection, electrical grid, site and supporting facilities, environmental protection, emergency planning, security and physical protection, nuclear fuel cycle, radioactive waste, industrial involvement, procurement, support for financing, risk allocate fund for feasibility study and allocation and opportunity to improve national capability.

\section{For this proposal it is required:}

1. BAEC may develop basic technological infrastructure and manpower to set up Nuclear Power Plant (NPP).

2. Manpower for operation and maintenance of the nuclear power plant may be trained in cooperation with the plant suppliers and a team on design aspects could be planned as part of overall contract with the main supplier.

3. Fresh professionals should be appointed for RNPP will be available general Universities, Universities of Engineering and Technology and Technical Institutes during implementation phase from annual output.

Besides these there is a scope to set up mini hydro power generation plant in hill tracts area of Bangladesh.

\section{Conclusion}

Electrical energy plays a vital role in development of civilization. The advancement of a country is measured in terms of per capital consumption of electrical energy. It is quite impossible to solve over all power crisis but possible to control load demand by using CFL, transferring holiday, transfer from peak to off-peak hour only through proper planning by load management, encouraging IPP, reducing transmission loss, more utilization of renewable energy sources. GOV should give priority to control misuse and corruption in power sector than generation of power. Alarming signal for the power sector in Bangladesh is the dependence of the coal/gas which may turn out. In that case our power sector will be collapsed and the nation will go back to dark from civilization. It is strongly recommended that to search alternative raw-materials for the production or immediate exploration of new gas and mining of coal deposits that are essential to implement the above power generation program. In that case nuclear power plant may not be the solution of power crisis in Bangladesh because of problems in operating a nuclear plant, the disposal and storage of the radioactive waste material produced by the plant. Bangladesh is a over populated country, any explosion like Chernobyl may destroy crore people. On the other hand already 50 years have crossed after pilot project in Rooppur no out put has come. It could be suggested that proper utilization of renewable energy may be the alternative way for solving the power crisis in Bangladesh because which is low cost and less risk. By incorporating IPP and local GOV, central GOV should take the responsibility to increase the power generation and ensure its proper use. Then the nation will find the way to reach with the developing nations.

\section{References}

Annual Report of Bangladesh Power Development Board (BPDB), 2006-07.

"A comprehensive report on wind power" by BPDB, 2007.

A publication of Spilling Energy System 2008 "Gas Expansion Power Plants with Modular System Gas Expanders" 27, 262-265.

Electrical and Electronic Engineering (EEE) Department, Islamic University of Technology (IUT), Gazipur, Bangladesh, December 2008, Lecture Handouts of the course on "Electricity-the Most Preferred Form of Energy: Need, Accessibility, Affordability and Sustainability".

Mansoor S.A. and Arshad Mansoor, 28-30 December 2004, "Power generation opportunities in Bangladesh from gas pressure reducing stations" 3rd International Conference on Electrical \& Computer Engineering, ICECE, Dhaka, Bangladesh.

Power Division, Ministry of Power, Energy \& Mineral Resources, Government of the People's Republic of Bangladesh (MPEMR, 2009).

www.bpdp.gov.bd

www.reein.org/wind

Received : February 08, 2009;

Accepted : August 24, 2009 